\title{
A 22-year-old man with chronic red eye and dysuria
}

\author{
Pierre R Rothschild, ${ }^{1}$ Antoine P Brezin, ${ }^{1}$ Nicolas Dupin ${ }^{2}$
}

${ }^{1}$ Department of Ophthalmology, Groupe hospitalier CochinHôtel-Dieu, AP-HP, Paris, France ${ }^{2}$ Department of Dermatology, Groupe hospitalier CochinHôtel-Dieu, APHP, Paris, France

\section{Correspondence to} Dr Pierre-Raphaël R Rothschild, pierreraphaelrothschild@ hotmail.com

Accepted 24 February 2014

\section{DESCRIPTION}

A 22-year-old man presenting with a long-standing ( $>4$ months) history of redness in his right eye accompanied by scant mucopurulent discharge was treated by several courses of topically administered antibiotics. Owing to the poor response to therapy, he was referred to our ocular inflammatory clinic. External examination of the right eye revealed prominent conjunctival follicles almost exclusively located at the inferior fornix of the conjunctiva (figure 1) and at the semilunar fold (figure 2). The rest of the examination was unremarkable except for a symptom of mild burning on urination for the past 3 months. Of importance, the patient was heterosexual. Microscopy, culture and sensitivity testing as well as nucleic acid amplification testing (NAAT) was performed on a conjunctival swab and first stream urinary specimen. NAAT confirmed the presence of Chlamydia trachomatis in both samples and excluded the presence of Neisseria gonorrhoeae. The patient was prescribed a 1-week course of oral doxycycline $100 \mathrm{mg}$ twice a day. Symptoms and signs resolved completely within 1-month thereafter.

C trachomatis is an obligate intracellular bacteria responsible for several types of eye infections depending on the serovar. ${ }^{1}$ Serovars $\mathrm{D}-\mathrm{K}$ cause sexually transmitted genital tract infections that frequently spread to the eye through genital and/or ocular infected secretions. A genital tract infection is confirmed in up to $80 \%$ of adults with chlamydial inclusion conjunctivitis. ${ }^{2}$ Frequently, the eye infection can represent the sole manifestation of the asymptomatic latent genital tract infection responsible for infertility in women worldwide. Of importance, a reactive arthritis can affect up to $50 \%$ of patients several weeks after the chlamydial genital infection.

In contrast to other causes of conjunctivitis, the suspicion of adult chlamydial inclusion conjunctivitis requires appropriate sampling. If confirmed, referral to a sexually transmitted disease clinic to test for other sexually transmitted infections, and

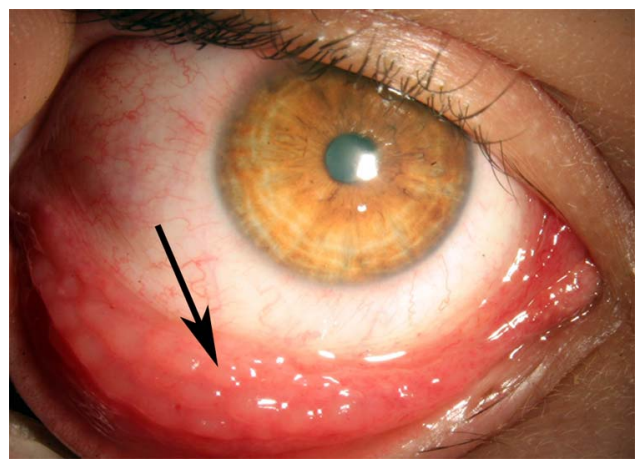

Figure 1 Large conjunctival follicles predominating at the inferior fornix (arrow).

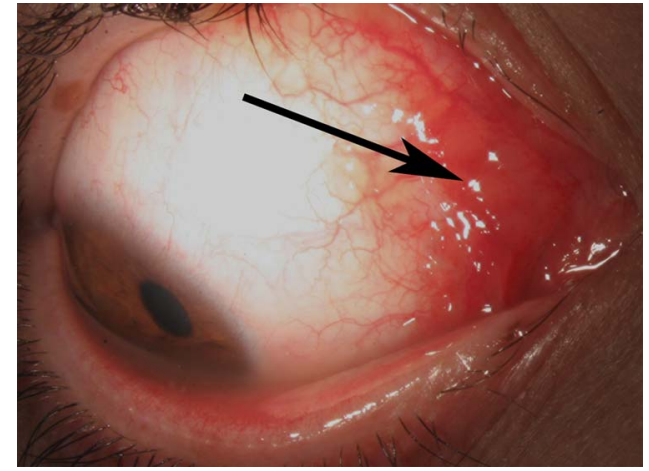

Figure 2 Prominent conjunctival bulbar follicles at the semilunar fold (arrow).

abstinence from intercourse until contacts have been treated is critical. Treatment guidelines recommend oral administration of azithromycin $(1 \mathrm{~g}$ single dose) or doxycycline (100 mg twice daily for 7 days)..$^{3}$

\section{Learning points}

- Chlamydia conjunctivitis has a chronic course and topical antibiotics are ineffective.

- Management requires microbiological testing, systemic antibiotics as well as sexually transmitted disease clinic referral.

- The eye infection can be the only detectable manifestation of the frequently associated genital tract infection that causes infertility in women worldwide.

Contributors P-RRR, APB and ND have been substantially involved in the management of the patient and have participated in the manuscript preparation.

\section{Competing interests None.}

Patient consent Obtained.

Provenance and peer review Not commissioned; externally peer reviewed.

\section{REFERENCES}

1 Mishori R, McClaskey EL, WinklerPrins VJ. Chlamydia trachomatis infections: screening, diagnosis, and management. Am Fam Physician 2012;86:1127-32.

2 Postema EJ, Remeijer L, van der Meijden WI. Epidemiology of genital chlamydial infections in patients with chlamydial conjunctivitis; a retrospective study. Genitourin Med 1996;72:203-5.

3 Geisler WM. Diagnosis and management of uncomplicated Chlamydia trachomatis infections in adolescents and adults: summary of evidence reviewed for the 2010 Centers for Disease Control and Prevention Sexually Transmitted Diseases Treatment Guidelines. Clin Infect Dis 2011;53(Suppl 3):S92-8. 
Copyright 2014 BMJ Publishing Group. All rights reserved. For permission to reuse any of this content visit http://group.bmj.com/group/rights-licensing/permissions.

BMJ Case Report Fellows may re-use this article for personal use and teaching without any further permission.

Become a Fellow of BMJ Case Reports today and you can:

- Submit as many cases as you like

- Enjoy fast sympathetic peer review and rapid publication of accepted articles

- Access all the published articles

- Re-use any of the published material for personal use and teaching without further permission

For information on Institutional Fellowships contact consortiasales@bmjgroup.com

Visit casereports.bmj.com for more articles like this and to become a Fellow 